\title{
GAYA BUSANA KERJA MUSLIMAH INDONESIA DALAM PERSPEKTIF FUNGSI DAN SYARIAH ISLAM
}

\author{
Pingki Indrianti \\ Magister Desain Fakultas Seni Rupa dan Desain-ITB \\ email: pingki.indrianti@gmail.com
}

\begin{abstract}
The phenomenon of hijab trend in Indonesia runs concurrently with the increasing number of working women who wear hijab particularly at a number of offices in major cities, both private and state agencies. However, the formal Muslimah's work clothes currently follow the trend with no regard to the suitability of the function of the work clothes and Islamic shari'a. This study aims at obtaining the criteria for Muslimah's work clothes, in terms of silhouette and materials used. The research method employed is literature review on the criteria, as well as the analysis of a number of Muslimah's work clothes images obtained from personal documentation, magazines, and online shops. The finding shows three groups of Muslimah work clothes: closed to shari'a criteria, to basic concept of work clothes, and to both groups. The perspective of modernist Islamic in Indonesia, regarding the forms of hijab is used as a benchmark for analyzing the Islamic shari'a criteria. Work clothes in accordance with the Islamic criteria, work functions and trends, are expected to help Muslimah workers dressed in syar'i, professional, and trendy hijabs.
\end{abstract}

Fenomena tren jilbab di Indonesia berjalan seiring meningkatnya jumlah pekerja wanita berjilbab, khususnya di sejumlah perkantoran di kota besar, baik instansi swasta maupun pemerintahan. Namun demikian, busana kerja muslim formal saat ini banyak yang hanya mengikuti tren tanpa memperhatikan kesesuaian fungsi busana kerja maupun syariah Islam. Penelitian ini bertujuan mendapatkan kriteria gaya busana kerja muslimah, baik dari segi siluet maupun penggunaan material. Metode penelitian yang digunakan yaitu kajian literatur mengenai kriteria busana kerja muslimah serta analisis sejumlah gambar 
busana kerja muslimah dari dokumentasi pribadi, majalah, maupun situs jualbeli di internet. Hasil analisis menunjukan tiga kelompok gaya busana kerja muslimah: mendekati kriteria syariah, mendekati konsep dasar busana kerja, dan irisan keduanya. Adapun pemikiran kaum Islam modernis di Indonesia mengenai aturan jilbab, digunakan sebagai acuan dalam menganalisis kriteria syariah busana muslimah. Busana kerja muslimah yang sesuai dengan kriteria syariah, konsep dasar busana kerja maupun tren, diharapkan dapat membantu karyawati muslimah berhijab secara syar'i, profesional, dan trendi.

Keywords: fashion, work chlotes, muslimah chlotes

\section{Pendahuluan}

Indonesia merupakan negara dengan jumlah penduduk muslim terbesar di dunia, hampir delapan puluh persen lebih masyarakatnya beragama Islam. Bersamaan dengan itu, pengguna jilbab terus bertambah dan tren busana muslimah pun semakin diminati. Dalam pagelaran fesyen tahunan seperti Jakarta Fashion Week dan Indonesia Fashion Week, busana muslimah selalu hadir dan ikut meramaikan fesyen di tanah air. Bahkan, Kementrian Perindustrian dan Perdagangan Indonesia sudah mulai menggalakkan kampanye "Menuju Indonesia sebagai Kiblat Fesyen Muslim Dunia Tahun 2020", sehingga masyarakat internasional akan mengingat negara Indonesia sebagai pusat bagi tren busana muslim yang ada di dunia. Tren jilbab di Indonesia saat ini tidak terlepas dari pengaruh tren fesyen Hijabers atau dikenal dengan sebutan Hijabers Community (Komunitas yang didirikan sebagai wadah bagi para wanita muda muslimah pengguna jilbab yang ada di Indonesia). Kelompok ini rutin menyelenggarakan acara fesyen serta memperkenalkan tren fesyen muslimah terbaru. Gaya berbusana kelompok Hijabers sangat ekspresif, modern, variatif dan penuh dengan kreatifitas baik dari segi teknik jahit, pola, bahan, motif maupun warna.

Fenomena Hijabers dan semakin meningkatnya jumlah pengguna jilbab di Indonesia, juga diiringi dengan meningkatnya jumlah pekerja wanita yang menggunakan jilbab khususnya pada sejumlah perkantoran formal di kota besar baik instansi swasta maupun pemerintahan. Banyak wanita muslimah yang memutuskan untuk menggunakan jilbab kemudian tetap bekerja dan harus menyesuaikan diri dengan lingkungan kantor, namun tidak ingin meninggalkan akidahnya. Hal tersebut memunculkan kebutuhan terhadap busana muslimah yang dapat memberikan rasa nyaman dalam beraktifitas di kantor sekaligus penampilan trendi tanpa meninggalkan segi syariah Islam. Namun demikian, banyak model busana kerja muslimah saat ini yang hanya mengikuti tren tetapi 
kurang sesuai dengan syariah Islam maupun memperhatikan segi kenyamanan dan kepraktisan. Penelitian ini bertujuan untuk mendapatkan kriteria gaya busana kerja muslimah, baik dari segi siluet maupun penggunaan material, sehingga didapatkan sejumlah variabel yang bermanfaat sebagai acuan bagi perancang mode dalam merancang desain busana kerja muslim, khususnya dari segi material, ukuran dan siluet.

\section{Pengertian Jilbab dalam Perspektif Syariah}

Secara etimologis, jilbab berasal dari bahasa Arab jalaba atau bentuk jamaknya jalabib, tercantum dalam surat al Ahzab ayat 59 (Surtiretna, dkk, 1995: 52). Banyak ulama dan ahli tafsir yang mengartikan kata jalaba atau jilbab sebagai busana muslimah, yaitu suatu pakaian wanita yang tidak ketat atau longgar serta menutupi seluruh tubuh wanita, kecuali muka dan telapak tangan (aurat). Pakaian tersebut dapat berupa baju luar semacam mantel yang dapat menutup atau melapisi pakaian dalam, namun dapat juga digunakan langsung tanpa pakaian dalam. Pakaian dalam menurut tafsiran ulama ini adalah pakaian yang digunakan oleh seorang wanita seperti blus dan rok (setelah sebelumnya menggunakan BH (bouste houder) dan celana dalam terlebih dahulu). Setelah menggunakan pakaian dalam tersebut seorang wanita yang ke luar rumah diharuskan menggunakan pakaian luarnya (jilbab), namun apabila pakaian dalamnya cukup tebal dan panjang menutup aurat, maka tidak perlu lagi menggunakan pakaian luar. Hanya tinggal menambahkan kerudung (khimar) dan kaus kaki sebagai salah satu model jilbab. Jilbab dengan hijab (berasal dari kata hajaba) yaitu tutup, bungkus, tirai, cadar, layar, partisi (Zulaikha, 2003: 10). Beberapa negara memiliki istilah berbeda dalam menyebut jilbab. Di Iran jilbab disebut dengan chador; India dan Pakistan pardeh, milayat di Libya; abaya di Irak; charshaf di Turki; tudung di Malaysia; dan hijab di beberapa negara Arab, Afrika, dan Eropa. Jilbab di Indonesia dalam KBBI online diartikan sebagai kerudung lebar yang dipakai perempuan muslim untuk menutup kepala dan leher sampai ke dada. Secara umum jilbab merupakan bagian dari rangkaian busana muslimah yang tidak ketat atau longgar serta menutupi tubuh kecuali muka dan telapak tangan.

Dalam agama Islam, berbusana (al Libaas) merupakan hal yang penting dan sensitif serta memiliki hukum yang wajib baik bagi kaum pria maupun wanita muslim karena berkaitan dengan masalah aurat, hal tersebut dijelaskan berulangkali pada beberapa ayat al Quran yaitu surat al A'raf: 26-27, an Nur: 58, an Nahl: 81, al Anbiya: 80, Saba': 11, dan Yusuf: 93. Beberapa penafsir 
menyimpulkan fungsi pakaian dalam sejumlah ayat al Quran: 1) Sebagai penutup aurat; 2) sebagai perhiasan; 3) pakaian sebagai syarat kesehatan, keamanan, melindungi diri dari gangguan luar dan menyelamatkan diri dari musuh yang mengancam (mengacu pada QS 16:81).

Sementara itu, beberapa kriteria jilbab sesuai dengan syariah Islam merujuk pada sejumlah hadits tentang pakaian (Surtiretna, dkk, 1996: 68), yaitu: 1) bagian tubuh yang terlihat hanya wajah dan telapak tangan, 2) tidak memperlihatkan lekuk tubuh dan tidak transparan (tekstil yang digunakan tidak tipis ataupun ketat 3) tidak menyerupai pakaian laki-laki, apabila ingin menggunakan celana panjang gunakan lah celana panjang yang longgar dengan blus menutup setengah paha hingga lutut (Surtiretna, dkk), serta 4) tidak berlebihan atau boros (israf), termasuk berlebihan dalam berpakaian atau berhias hingga mengundang syahwat lelaki yang bukan muhrimnya.

\section{Sejarah Singkat Busana Muslim di Indonesia}

Sejak agama Islam masuk ke Nusantara, wanita dan pria muslim tidak memiliki cara berpakaian yang berbeda dengan orang-orang pribumi lainnya (Prasetya, 2010: 67). Belum ada istilah busana muslim, namun sedikit demi sedikit diiringi dengan kewajiban berhaji umat Islam ke kota suci Mekah, maka banyak orang muslim yang mulai menggunakan pakaian yang ditiru dari gaya berbusana masyarakat Arab. Laki-laki menggunakan jubah berwarna putih sedangkan perempuan menggunakan kerudung yang saat itu di Indonesia bentuknya longgar dan masih memperlihatkan bagian rambut dan leher. Kendati Islam telah dianut masyarakat Nusantara sejak berabad silam, jenis pakaian yang menutup rapat anggota tubuh tidak dikenal terutama oleh kaum wanita muslim termasuk para aktivis pesantren. Hingga tahun 1930-an pakaian tradisional wanita pribumi di Nusantara masih berupa baju kurung dengan kerudung longgar, berkain kebaya dan menggunakan selendang. Busana yang berasal dari khazanah berpakaian orang Arab tersebut lambat laun tergantikan dengan munculnya kaum terpelajar pada masa kolonial Belanda yang menggunakan cara berpakaian Eropa. Pakaian tradisional (pribumi) menjadi identik dengan keterbelakangan dan mulai ditinggalkan bahkan jilbab atau kerudung menjadi simbol masyarakat pinggiran (Zulaikha, 2003: 57).

Pada akhir tahun 1980, revolusi Iran mempengaruhi kebangkitan Islam di seluruh dunia, termasuk di Indonesia khususnya dan berdampak pada penggunaan jilbab yang dikenal dengan masa "revolusi jilbab". 
Saat itu sejumlah aktivis wanita muslim mencoba menunjukan identitas keagamaannya melalui penggunaan jilbab yang menutup rapat kepala sesuai dengan syariah Islam. Namun demikian jilbab banyak ditentang oleh berbagai pihak termasuk pemerintah yang saat itu berada pada masa rezim Orde Baru. Gaya jilbab yang menutup rapat kepala dianggap sebagai lambang Islam radikal maupun perlawanan terhadap pemerintah orde baru saat itu. Sejumlah instansi pendidikan, kantor, hingga pemerintahan bahkan mengeluarkan larangan tentang penggunaan jilbab. Barulah pada awal tahun 90-an, penggunaan jilbab menjadi lebih bebas. Hal tersebut merupakan dampak dari mulai dirangkulnya sejumlah organisasi Islam oleh pemerintah Orde Baru terlebih setelah era reformasi pada tahun 1998. Pengguna jilbab mengalami peningkatan pesat, model jilbab dan busana muslim pun semakin bervariasi didukung oleh banyaknya artis yang mulai menggunakan jilbab seperti Inneke Koesherawati, Ratih Sanggarwati, Zaskia Mecca, dan lain sebagainya. Pada tahun 2010, muncul tren Hijabers yang dipopulerkan oleh Hijabers Community, sebuah komunitas wanita muslimah pengguna jilbab, komunitas ini menawarkan konsep busana muslimah yang muda, modern, dan trendi. Sejak kemuncukan komunitas ini, pengguna jilbab di Indonesia semakin bertambah pesat, khususnya di kalangan kaum muslimah muda atau remaja.

\section{Model Jilbab dalam Ragam Paham Keislaman di Indonesia}

Pada dasarnya umat Islam di Indonesia memiliki pemahaman yang terbuka terhadap datangnya sebuah kebudayaan baru, demikian juga dalam pemahaman beragama. Islam yang masuk ke Indonesia melalui proses akulturasi budaya memudahkan masyarakat untuk menerima dan memeluk agama Islam. Namun demikian keterbukaan inilah yang ternyata membagi umat Islam di Indonesia menjadi beberapa pola pemikiran dan pemahaman dalam menafsirkan ajaran agama Islam seperti al Quran dan hadits. Hal inilah yang kemudian memunculkan berbagai persepsi mengenai bentuk jilbab dan batasan aurat wanita muslimah.

Beberapa pemahaman tersebut terbagi menjadi dua kelompok besar, yaitu tradisionalis dan modernis, kemudian dalam perjalanannya semakin bertambah diantaranya kelompok Islam Neomodernis atau Liberalis hingga Fundamentalis.

1. Jilbab Menurut Pandangan Kaum Tradisionalis

el Harakah Vol.15 No.2 Tahun 2013 
Kelompok Islam tradisionalis diartikan sebagai kelompok dengan pola pikir ke-Islaman yang terikat pada hasil pemikiran ulama yang hidup antara abad ketujuh hingga ketiga belas (Zenrif, 2011: 17). Kelompok ini secara historis mendominasi seluruh pendekatan perkembangan penafsiran ajaran Islam masa awal. Tafsir pada masa itu hingga abad pertengahan, bahkan masih digunakan hingga sekarang, menggunakan pendekatan tekstual, literal, normatif. Pendekatan ini berimplikasi terhadap produk pemikiran skriptualis dan formalistik yang kemudian menjadi ciri khusus kelompok Islam tradisional hingga sekarang.

Pada beberapa gerakan Islam tradisional, pengaruh kebudayaan lokal sangat kuat seperti yang terjadi pada kelompok tradisionalis di Indonesia. Hal ini tentu saja sangat berbeda dengan sejumlah tradisionalis di negara timur tengah. Islam tradisionalis, khususnya di negara Indonesia, lebih bersifat terbuka dalam menerima kebudayaan baru di luar agamanya. Misalnya pada Islam tradisionalis di Jawa yang disebarkan oleh Wali Sanga kemudian dikenal dengan istilah Islam Kejawen. Salah satu metode atau cara penyampaian agama Islam yang digunakan Kejawen adalah 'sinkretisme' yaitu tata cara kepercayaan masyarakat pribumi lama (agama hindu) digunakan sebagai alat penerangan syiar Islam yang kemudian lambat laun diluruskan agar masyarakat lekas bisa mengikuti ajaran Islam dengan benar. Sinkritisme dan toleransi merupakan watak dasar keagamaan orang Islam di Jawa yang selalu membuka diri dan bersikap arif terhadap interpretasi maupun olahan baru dari sebuah paham (Endraswara, 2012: 48). Karena kentalnya budaya Jawa pada ajaran Islam tradisionalis, maka wanita muslimah di Indonesia pada masa itu memilih berbusana yang sesuai dengan tradisi kulturnya, seperti kebaya dan kerudung longgar. Tidak menggunakan model busana muslimah seperti yang digunakan oleh wanita arab (berwarna hitam panjang dan menutup rapat aurat). Hingga akhir abad ke 20, sebagian besar wanita Jawa menggunakan kain kebaya yang terbuka, begitu pula pada wanita muslimah yang aktif di pesantren, beberapa hanya menggunakan kerudung longgar yang masih memperlihatkan rambut dan leher (Prasetya, 2010: 68). Beberapa contoh organisasi masa (ORMAS) saat ini yang menganut Islam tradisionalis yaitu Nahdhatul Ulama, Qadiriyah Naqsyabandiyah, dan gerakan Jema'ah Tabligh.

\section{Jilbab Menurut Pandangan Kaum Modernis}

Islam modernis muncul setelah masuknya pengaruh modernisasi Islam pada abad ke-19 di Mesir, mereka memiliki pemikiran dan gagasan baru 
terhadap agama Islam yang lebih modern. Islam modernis pada awalnya berasal dari Islam tradisionalis yang menggunakan acuan tafsir Islam 7 abad VII-XIII Masehi. Kelompok Islam modernis didefinisikan sebagai kelompok yang berpandangan bahwa adanya perkembangan ilmu pengetahuan berpengaruh pada perkembangan budaya kontemporer, mengharuskan umat Islam untuk menafsirkan kembali ajaran-ajaran agama yang dianggap usang, atau melakukan pembaruan terutama yang berkaitan dengan permasalahan sosial sebagai produk akal manusia (Zenrif, 2011: 19). Berangkat dari pandangan ini, kalangan modernis menggunakan keilmuan modern atau keilmuan barat, seperti psikologi, sejarah, sosiologi dan antropologi dalam menafsirkan ajaran Islam, yang kemudian disebut dengan pendekatan kontekstual. Pemikiran Islam modern semakin cepat bisa diterima di kalangan akademisi, seiring kelompok ini berhasil menguasai hampir seluruh pemikiran kalangan akademisi, khususnya di Perguruan Tinggi Agama Islam karena sifat pemikirannya yang progresif, terbuka, dinamis, dan mengalami penyesuaian terhadap ilmu pengetahuan.

Secara keseluruhan, dapat disimpulkan bahwa yang dimaksud dengan Islam modernis adalah Islam yang mendasari pemahaman dan penafsiran agamanya dengan ilmu pengetahuan modern atau ilmu pengetahuan barat namun tetap mengacu pada ahli tafsir dan fiqih terdahulu. Islam modernis di Indonesia pada mulanya berasal dari kaum tradisionalis, namun dilandasi oleh keinginan untuk melakukan pembaruan serta melepaskan diri terhadap sinkretisme tradisionalis (Islam kejawen), maka terbentuklah kaum modernis. Kaum Islam modernis cukup ketat dalam menerapkan batasan aurat wanita muslimah, seperti harus menutup rapat seluruh aurat kecuali muka dan telapak tangan. Namun demikian, model atau gaya busana masih dibebaskan pada pemakainya, misalnya diperbolehkan mengadopsi tren mode barat asalkan masih sesuai dengan kaidah Islam. Ormas penganut Islam modernis adalah Muhammadiyah dan Persatuan Islam (PERSIS).

\section{Jilbab Menurut Pandangan Kaum Fundamentalis}

Terdapat dua jenis Islam fundamentalis, yaitu fundamentalis literaris dan liberaris. Keduanya memiliki cara yang berbeda dalam memeluk syariah Islam, yang satu bersifat radikalis sedangkan yang lain moderat. Walaupun keduanya memiliki istilah yang sama, namun kata fundamentalis lebih diarahkan kepada Islam radikal. Sebaliknya, Islam moderat disebut sebagai Islam liberaris atau Neomodernisme (Zenrif, 2011: 21). Umat Islam secara umum dan golongan fundamentalis secara khusus, sering membandingkan kemunduran diri dengan 
kemajuan golongan lain, yaitu kejayaan generasi terdahulu. Melihat kejayaan tersebut, umat Islam yang berusaha maju memiliki empat opsi yaitu dengan mengulang kejayaan masa lalu, meniru golongan lain, membuang satu di antara keduanya, atau membuang keduanya dan berkreasi sendiri (Syafaq, 2009: 8). Dalam hal ini, Islam fundamentalis lebih suka memilih pengulangan kejayaan masa lalu dan membuang produk golongan lain. Oleh karena itu, kelompok ini juga sering disebut sebagai gerakan revivalis. Secara ideologis, tindakan radikal muslim fundamentalis, khususnya di Mesir, timbul dari pemikiran radikal. Mereka muncul dari suatu landasan berpikir yang didekati dengan metode berpikir ekstrim. Namun, secara sosiologis, kemunculan gerakan mereka karena adanya penekanan dan penindasan (atas jumlah mereka yang minoritas).

Karakteristik kaum fundamentalis literaris secara umum berpandangan ortodoks, intoleran dan anti-interpretasi. Salah satu contohnya adalah menghilangkan praktik-praktik takhayul dan bid'ah, hal ini dapat berarti seluruh perilakunya dikembalikan lagi kepada zaman Rasulllah SAW terdahulu (termasuk menghindari hal-hal yang besifat modern) (Sumbulah, 2010). Dalam hal berbusana, muslimah fundamentalis cenderung bersikap skeptis terhadap tren busana barat. Beberapa dari mereka ada yang memilih untuk menggunakan cadar berwarna gelap seperti yang digunakan oleh para wanita muslim di negara Arab. Beberapa contoh aktivis fundamentalis di Indonesia diantaranya adalah KISDI (Komite untuk Solidaritas Dunia Islam), KAMMI (Kesatuan Aksi Mahasiswa Muslim Indonesia), dan FPI (Forum Pembela Islam).

\section{Jilbab Menurut Pandangan Kaum Neomodernis}

Dalam kajian mengenai Islam neomodernis (liberalis) di Indonesia, dijelaskan bahwa gerakan neomodernis berkembang pada akhir 1960-an dan awal 1970-an, terutama di kalangan mahasiswa yang berlatar belakang tradisionalis. Komunitas mahasiswa ini merupakan generasi pertama dari muslim tradisionalis yang memiliki akses pada pendidikan (Tualeka, 2009: 24). Untuk memperluas wawasan keilmuannya, di antara mereka terlibat organisasi mahasiswa yang berorientasi modern seperti HMI atau Himpunan Mahasiswa Islam. Awalnya gerakan para intlektual muda tersebut merujuk pada pembaruan pemikiran Islam. Namun, gerakan itu akhirnya lebih mengarah pada neomodernis, dengan mengikuti paradigma gerakan pembaruan modern Fazlur Rahman, seorang pemikir Islam asal Pakistan yang menempuh pendidikan modern serta merupakan tokoh utama dari Neomodernisme. Rahman memetakan empat 
gerakan pembaruan Islam yang pernah muncul sepanjang dua abad dalam dunia Islam. Pertama, gerakan revivalis Islam, yang ditandai dengan gerakan Wahabisme dan Sanusisme. Kedua, gerakan Islam modernis atau modernisme klasik. Ketiga, gerakan Neorevivalis atau neo-fundamentalis. Keempat, gerakan Neomodernis. Gerakan terakhir ini muncul di kalangan intelektual muda, termasuk di Indonesia yang ingin kembali pada semangat modernisme awal, namun mencari kombinasinya dengan warisan kekayaan keilmuan Islam klasik. Gagasan ide pembaruan dan pemahaman liberal diterima secara luas oleh masyarakat Indonesia dan mampu mengubah sikap-sikap sosial yang cukup mendasar (Tualeka, 2009: 25).

Penyebaran gerakan Islam neomodernis di Indonesia semakin meluas antara lain berkat bergabungnya para intelektual muslim lain seperti Djohan Effendi, Ahmad Wahib, Dawam Rahardjo, Syu'bah Asa, dan Utomo Danan Jaya. Abdurrahman Wahid, sekembalinya dari studi di Timur Tengah yang secara cepat beraliansi dengan gerakan itu. Sebagai konsekuensinya, beberapa perhimpunan pemuda di bawah NU dan kebanyakan ulama yang sering bertukar ide dengan Abdurrahman Wahid secara kuat dipengaruhi oleh pemikiran neomodernis.

Neomodernisme di Indonesia seperti tercermin dalam pemikiran Nurcholish Madjid dan Abdurrahman Wahid memiliki beberapa karakteristik seperti berwatak progresif, terbuka, inklusivitas, dan pemahaman liberal Islam yang dapat diterima oleh segala kalangan, pengakuan pluralisme sosial, penekanan perlunya toleransi, dan hubungan harmonis di kalangan masyarakat. Dalam hal berbusana sejumlah ahli agama dalam kelompok neomodernis percaya bahwa menutup aurat dengan jilbab tidak harus menggunakan kain kudung untuk menutup kepala seperti yang sudah ditafsirkan selama ini. Bagi mereka, berjilbab atau tidak itu pilihan yang terpenting adalah menjaga hatinya.

Berdasarkan pembahasan di atas, keempat kaum muslim di Indonesia; tradisionalis, modernis, fundamentalis, dan neomodernis, memiliki cara pandang yang berbeda dalam menafsirkan ajaran agama Islam (al Quran dan hadits) seperti dalam menafsirkan jilbab dan batasan aurat wanita muslimah. Kelompok modernis, khususnya Muhammadiyah dan PERSIS, memandang jilbab sebagai sesuatu yang wajib menutup kepala dengan rapat, dada, dan punggung. Meskipun demikian, kelompok ini sangat terbuka dengan gaya berbusana lain asalkan masih sesuai dengan aturan syariah Islam. Sebaliknya kaum Islam fundamentalis lebih tertutup dan cenderung bersikap skeptis terhadap pembaruan khususnya tren mode busana atau fesyen, walupun tidak 
seluruhnya bersikap demikian. Sedangkan Islam neomodernis lebih bebas dalam memandang hal ini, bagi kaum ini menggunakan, tidak menggunakan atau menanggalkan jilbab sesungguhnya merupakan pilihan, apapun alasannya. Dari keempat pandangan berbeda dari masing-masing kelompok, setiap muslimah berhak untuk meyakini dan merujuk pandangan kelompok tertentu.

Dalam penelitian ini, pemikiran kaum tradisionalis dan modernis tentang jilbab digunakan untuk menilai batasan aurat muslimah. Berdasarkan pengamatan, umumnya muslimah di Indonesia mengacu pada penafsiran Islam tradisionalis dan modernis, walaupun kebanyakan dari mereka bukan pengikut fanatik. Pemikiran kedua kaum ini dianggap dapat mewakili pemikiran mayoritas muslim Indonesia. Sebut saja dua kelompok besar Islam di Indonesia yang banyak menjadi pegangan kaum muslim di Indonesia. Nahdatul Ulama (NU) yang mewakili mayoritas muslim tradisionalis Indonesia serta kelompok Muhammadiyah yang mewakili kaum modernis. Kedua kelompok ini bersifat terbuka namun masih memegang fiqih Islam.

\section{Kriteria Busana Kerja Muslimah}

Variabel yang digunakan dalam menentukan kriteria busana kerja muslim mengacu pada beberapa unsur dasar fesyen Elaine Stone yaitu siluet (termasuk ukuran) dan material (texture) yang kemudian dianalisis berdasarkan fungsi busana kerja dan syariah Islam.

\section{Siluet (Silhouette)}

Siluet busana dapat diartikan sebagai penampakan kontur busana secara keseluruhan serta merujuk pada bentuk busana (Stone, 2008: 9). Berikut beberapa karakteristik siluet beradasarkan syariah dan fungsi busana kerja.

2. Siluet Busana Berdasarkan Syariah

Kriteria siluet busana muslimah menurut fatwa Muhammadiyah yang diambil dari situs resmi Muhammadiyah mengenai aurat dan jilbab, merujuk pada al Quran maupun hadits yaitu: 1) menutup seluruh tubuh, termasuk kepala, dada, dan punggung, yang boleh terlihat hanya wajah dan telapak tangan (sampai pergelangan), 2) busana tidak ketat atau tidak membentuk lekuk tubuh terutama payudara, pinggang, dan pinggul serta memiliki potongan yang longgar, dalam hal ini berarti mengikuti siluet rectangular, wedge, maupun A line (Surtiretna, dkk, 1995: 68-69).

Siluet busana muslim juga tidak boleh menyerupai pakaian laki-laki. Adapun penggunaan celana panjang untuk wanita muslim dapat disiasati dengan 
menggunakan celana panjang yang longgar, misalnya celana kulot atau celana pipa berpotongan longgar, serta menggunakan blus hingga menutup setengah paha atau baju kurung. Paduan busana tersebut selain tidak membentuk tubuh bagian bawah (kaki) juga lebih menegaskan citra tidak menyerupai pria karena tidak ada pria yang menggunakan celana panjang dengan baju kurung maupun jilbab (kerudung) kecuali laki-laki yang bersorban.

3. Siluet Berdasarkan Konsep Dasar Busana Kerja

Busana kerja merupakan busana yang dipakai seseorang ketika melakukan pekerjaannya sesuai dengan profesi masing-masing baik pekerjaan formal maupun informal, luar ruangan (out door) maupun dalam ruangan (indoor), pekerjaan yang memerlukan fisik atau yang lebih banyak memerlukan pikiran (Riyanto, 2009: 39). Begitu juga jenis busana menurut kesempatannya, ada busana kantor untuk acara formal (resmi) maupun busana untuk acara semi formal (setengah resmi). Secara umum beberapa karakteristik dan siluet busana kerja diantaranya: 1) model busana kerja wanita (blus, rok, celana) praktis dan formal. 2) Model busana kerja sederhana tidak banyak lipatan, plooi, kerutan, jahitan tindis, dan saku. 3) Dapat menggunakan model busana tailored cut atau busana mantel pak (untuk nuansa formal) seperti (blazer) atau jas (suit). 4) Siluet busana kerja sopan, seperti potongan rok tidak mini, tidak menggunakan lengan berpotongan kutung (you can see), blus atasan dan rok (juga celana) tidak ketat (Riyanto, 2009: 61).

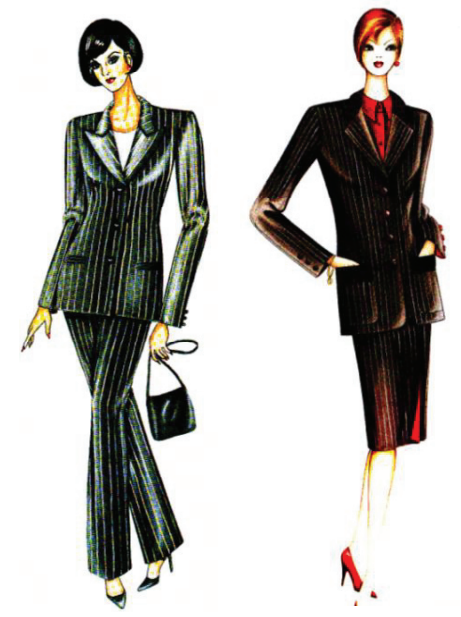

Gambar 1. Contoh model busana kerja (Riyanto, 2009)

Karakterisitik seragam kerja adalah: 1) potongan busana harus nyaman dan sopan, serta mendukung aktifitas kerja, 2) bentuk potongan busana 
bergaya klasik atau konservatif (stelan rok, blus, dan jas). Selain itu, beragam aktifitas wanita karir menuntut mereka untuk menghadiri pertemuan resmi dan setengah resmi dalam jam kantor, sehingga muncul model busana kerja wanita dengan model dressed-up (untuk busana resmi) yaitu busana yang tinggal menambahkan sesuatu di atas busana tersebut, bross, corsage, scarf atau kalung. Selain itu, ada juga model dressed-down yaitu dengan mengurangi kelengkapan yang dipakai untuk keperluan acara sosial atau bisnis (Dharsono, 1993: 13-15).

\section{Material (Texture)}

Berdasarkan fungsi busana kerja, material untuk busana kerja adalah kain yang dapat memberikan kesan nyaman, tidak tembus pandang, mengkilap serta tidak terlalu tebal dan kasar (Riyanto, 2009: 71). Sementara itu beberapa hal yang perlu diperhatikan dalam pemilihan bahan pakaian seragam adalah menggunakan bahan yang kuat (tahan lama) karena digunakan dalam aktifitas bekerja sehari-hari, serta mudah dalam perawatannya. Sedangkan material berdasarkan aturan syariah Islam adalah material berupa kain yang tidak tipis atau tidak transparan, sesuai dengan sabda Rasullullah SAW dalam beberapa hadits riwayat Abu Dawud dan Ahmad (Surtiretna, 1995: 59,69). Adapun kain transparan tersebut ditakutkan dapat memancing fitnah dari pihak laki-laki. Wanita yang menggunakan pakaian tipis dalam Islam disebut juga sebagai kasiyatun 'ariyat, Rasullullah SAW mengancam wanita yang berpakaian tetapi sebenarnya telanjang. "wanita seperti itu tidak akan masuk surga dan tidak akan mencium baunya, walaupun baunya tercium selama perjalanan sekian dan sekian”.

Berdasarkan penjelasan di atas, maka dapat ditarik kesimpulan bahwa bahan atau material busana kerja muslim yang sesuai dengan syariah dan fungsi busana kerja adalah: 1) bahan cukup tebal (tidak tipis) dan tidak tembus pandang seperti bahan wol, tweed, katun, suede, atau jika ingin menggunakan bahan tipis seperti sifon harus dilapisi dengan kain penutup (furing), 2) Bahan tidak mengkilap, warna tidak mencolok mata, 3) bahan nyaman digunakan dan mendukung aktifitas bekerja, 4) perawatan bahan harus mudah karena busana cenderung sering digunakan, 5) penggunaan ornamen atau ragam hias pada material tidak berlebihan atau terlalu ramai untuk mengejar kesan formal.

\section{Analisis Gaya Busana Kerja Muslim}


Analisis dilakukan untuk melihat wujud visual gaya busana kerja muslimah yang sesuai dengan kriteria. Metode yang dilakukan adalah melakukan penilaian terhadap sejumlah foto busana kerja muslim wanita, baik yang didapatkan melalui majalah, situs jual-beli online, dan dokumentasi pribadi. Pada setiap gambar, variabel siluet dan material diberikan poin $1-5$ sesuai dengan ketentuan Syariah Islam (S) dan fungsi (F) busana kerja.Lihat tabel 1 menunjukkan beberapa analisis gaya busana kerja muslimah.

Tabel 1. Analisis gaya busana kerja muslim

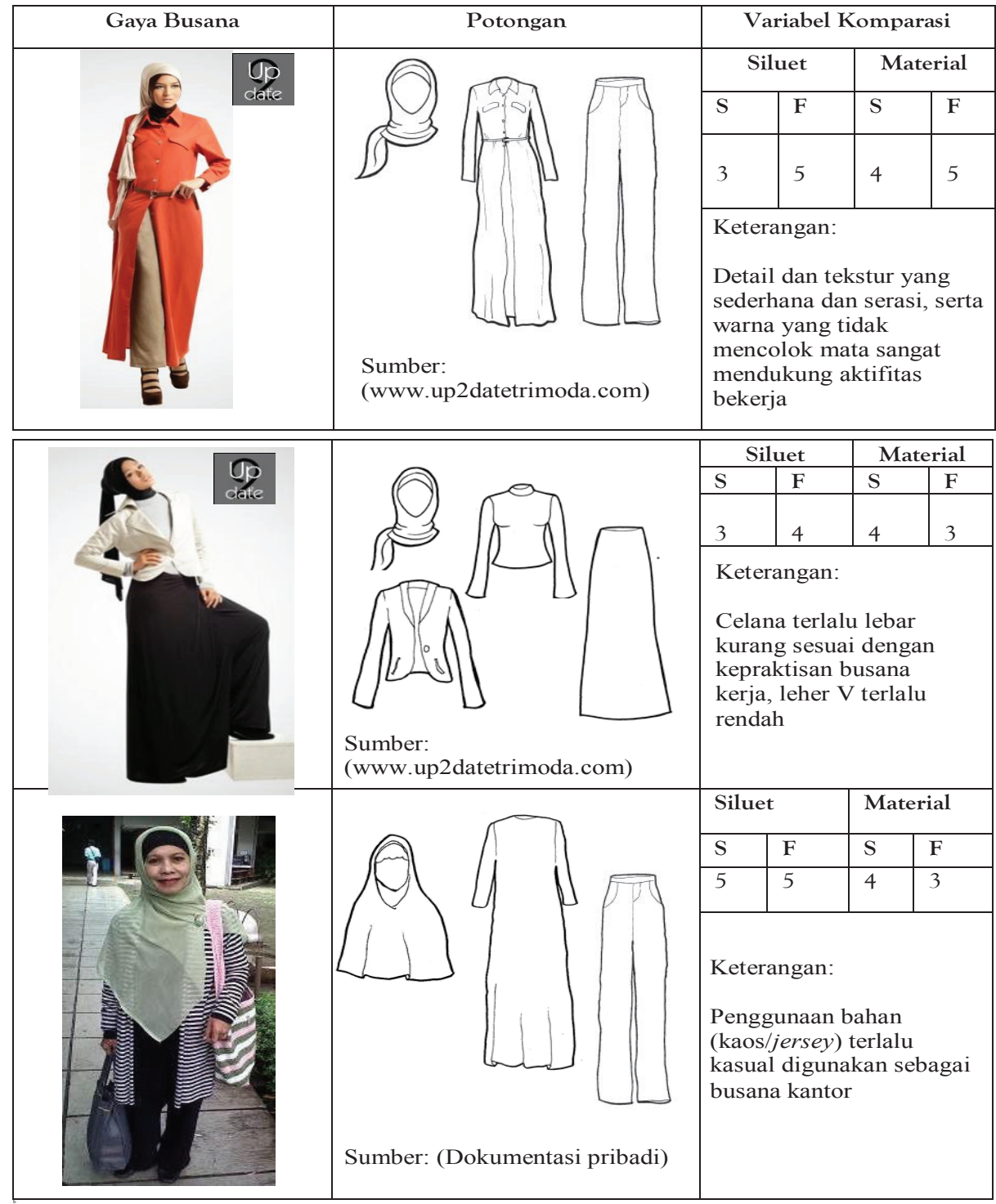




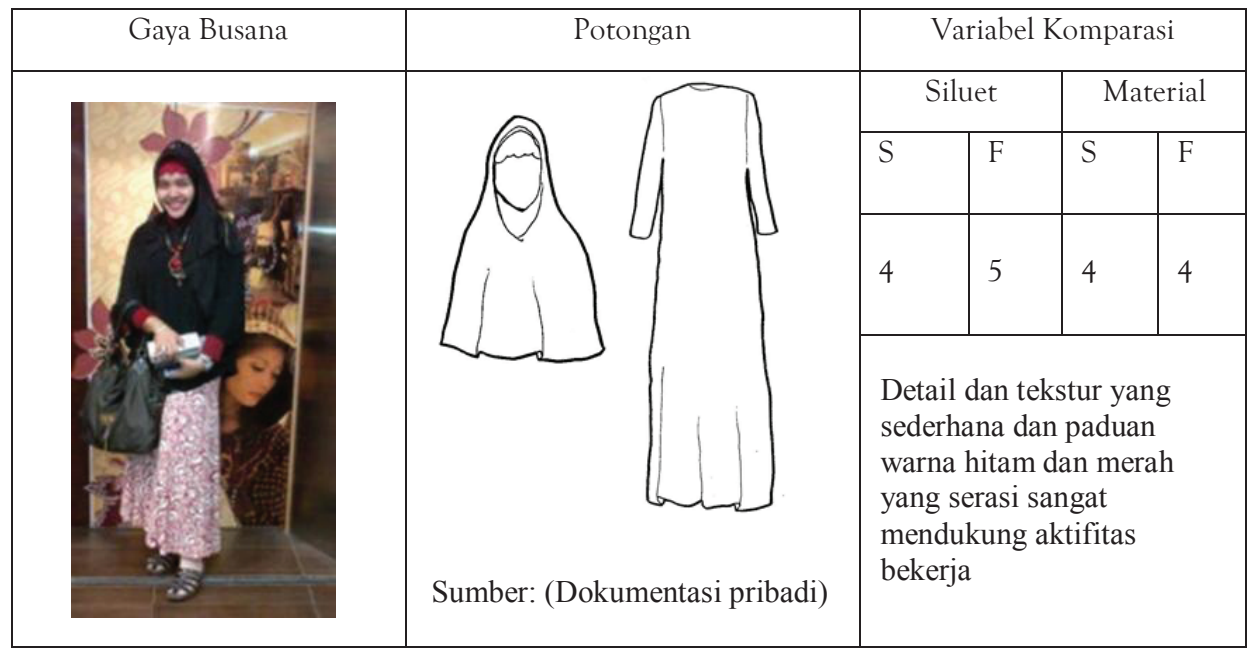

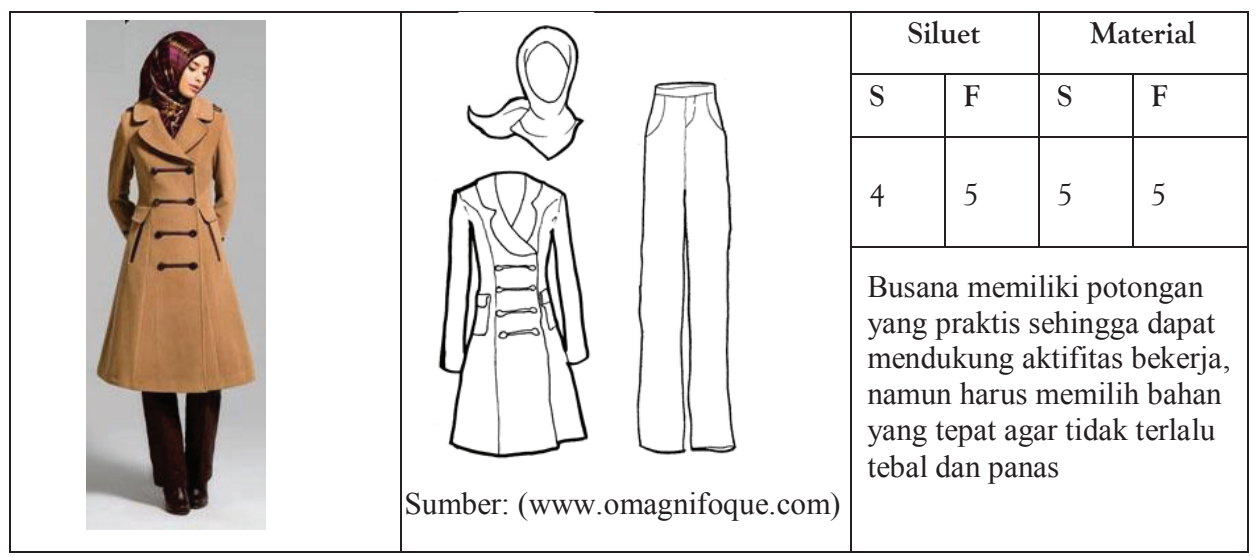

\begin{tabular}{|l|l|l|l|}
\hline \multicolumn{2}{|c|}{ Siluet } & \multicolumn{2}{|c|}{ Material } \\
\hline & $\mathrm{S}$ & $\mathrm{F}$ & $\mathrm{S}$ \\
\hline
\end{tabular}




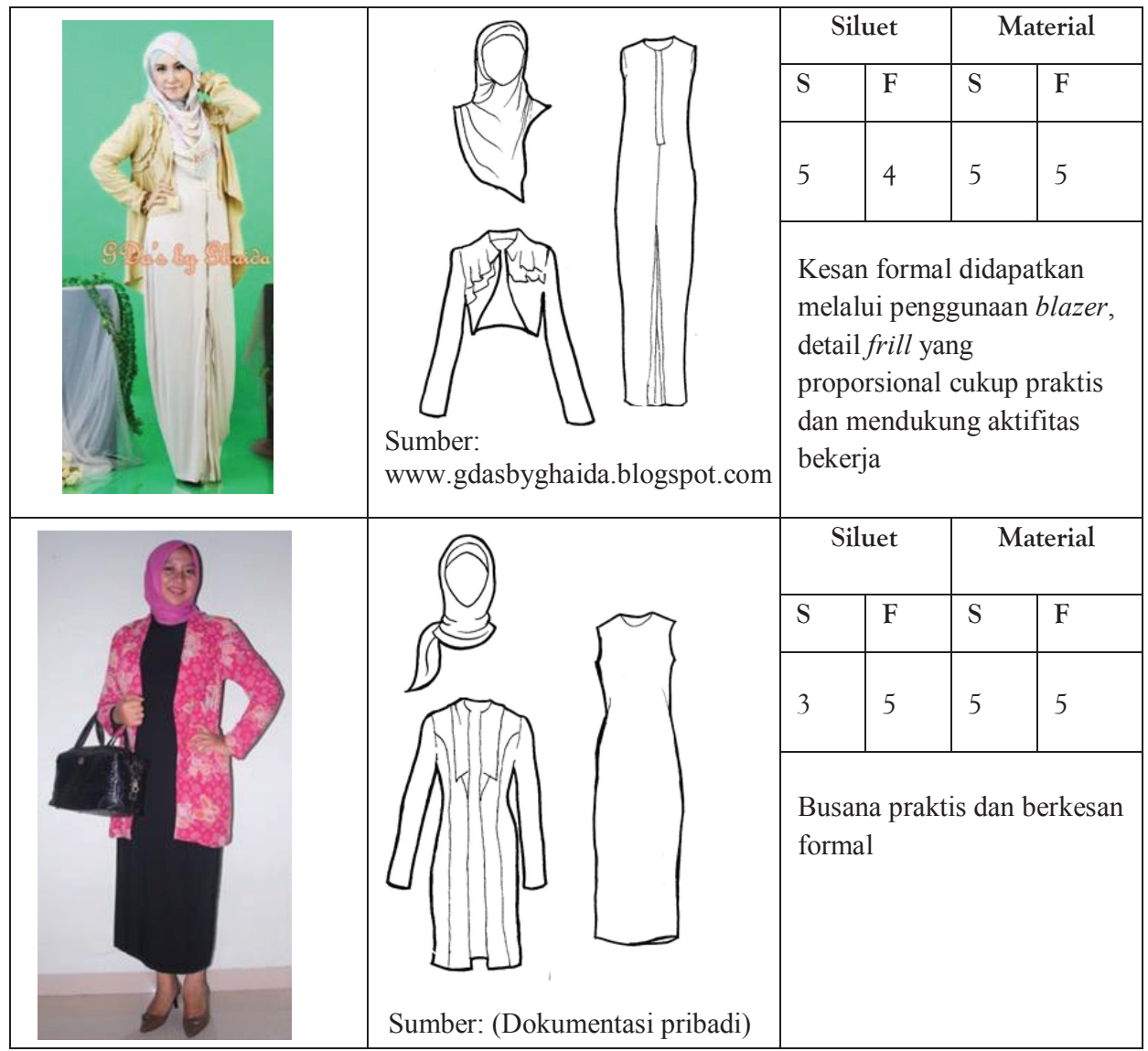

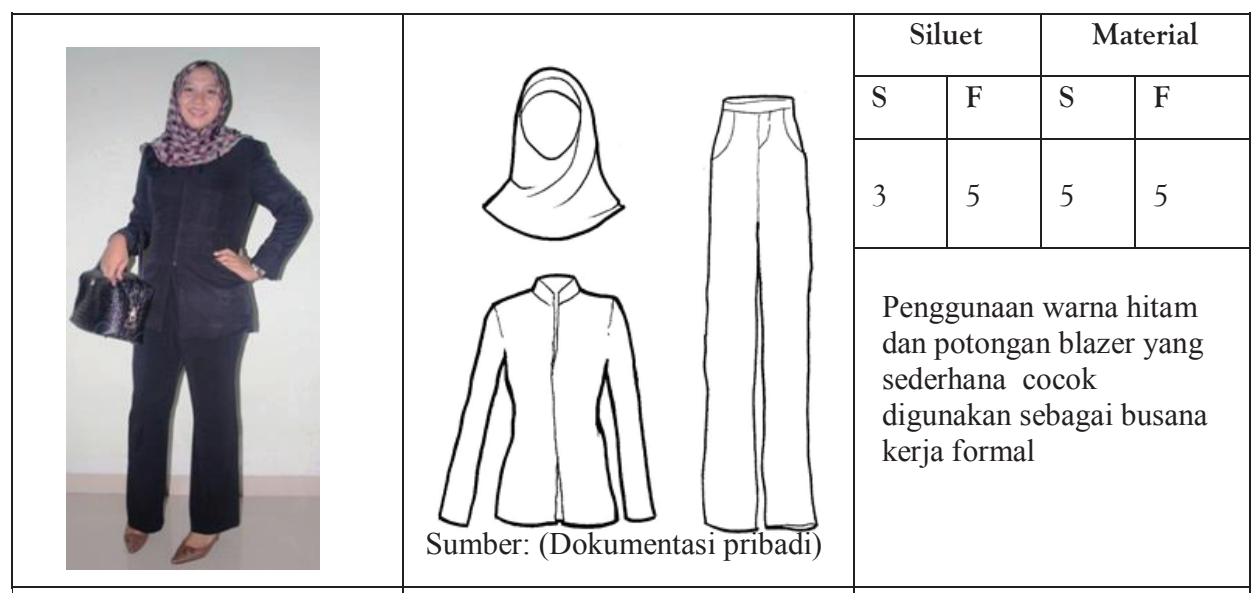

el Harakah Vol.15 No.2 Tahun 2013 


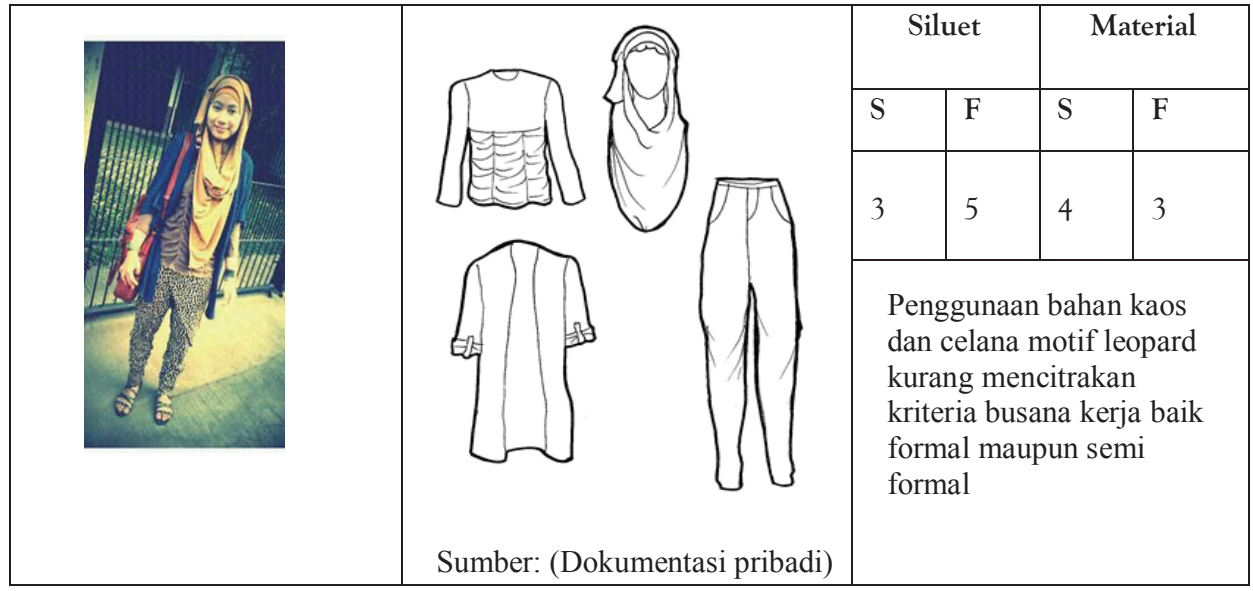

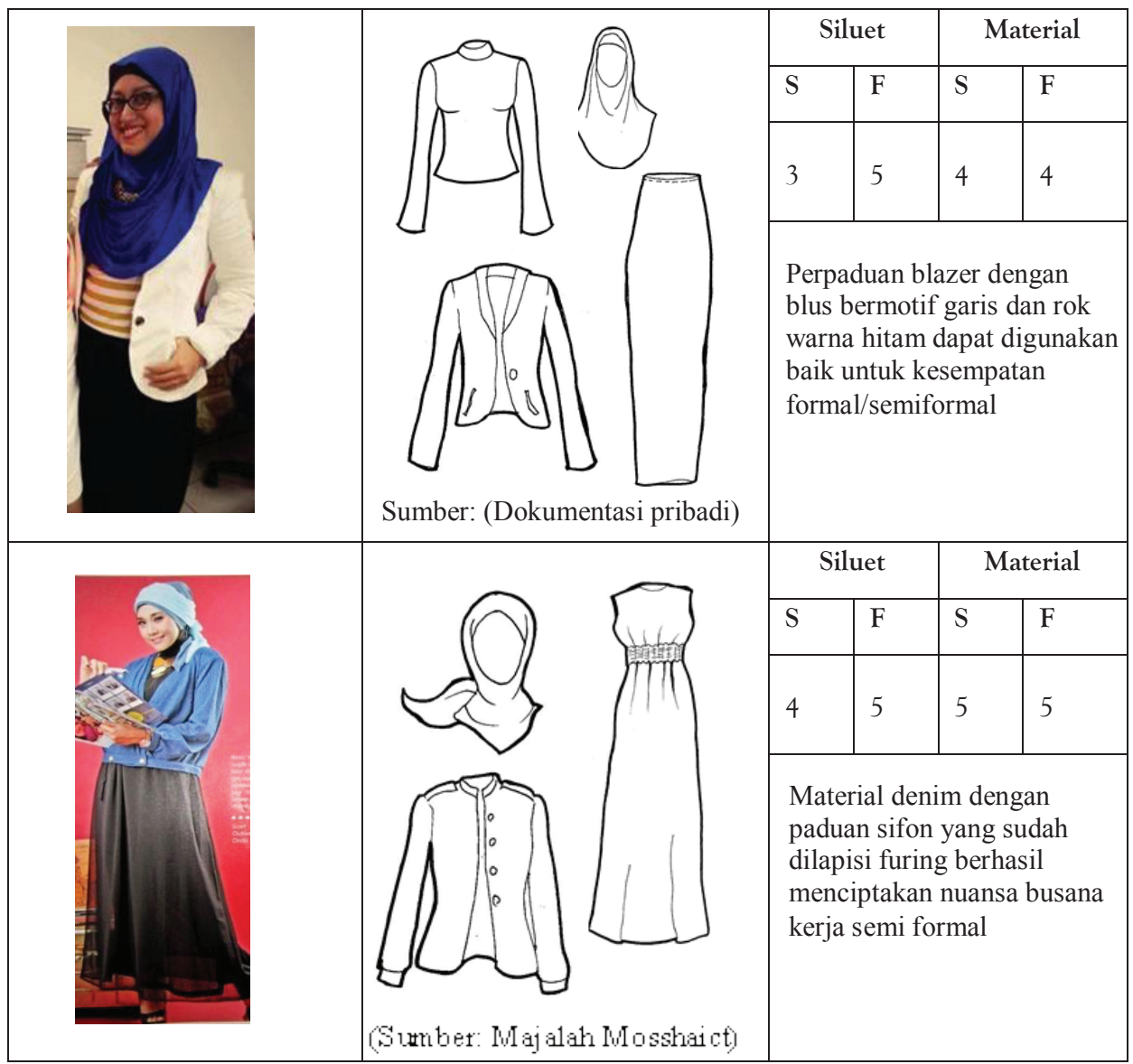


Berdasarkan analisis gambar di atas maka didapatkan hasil sebagai berikut:

1. Gaya busana dengan siluet yang sesuai maupun mendekati kriteria syariah (poin 4-5) terdapat pada gambar:
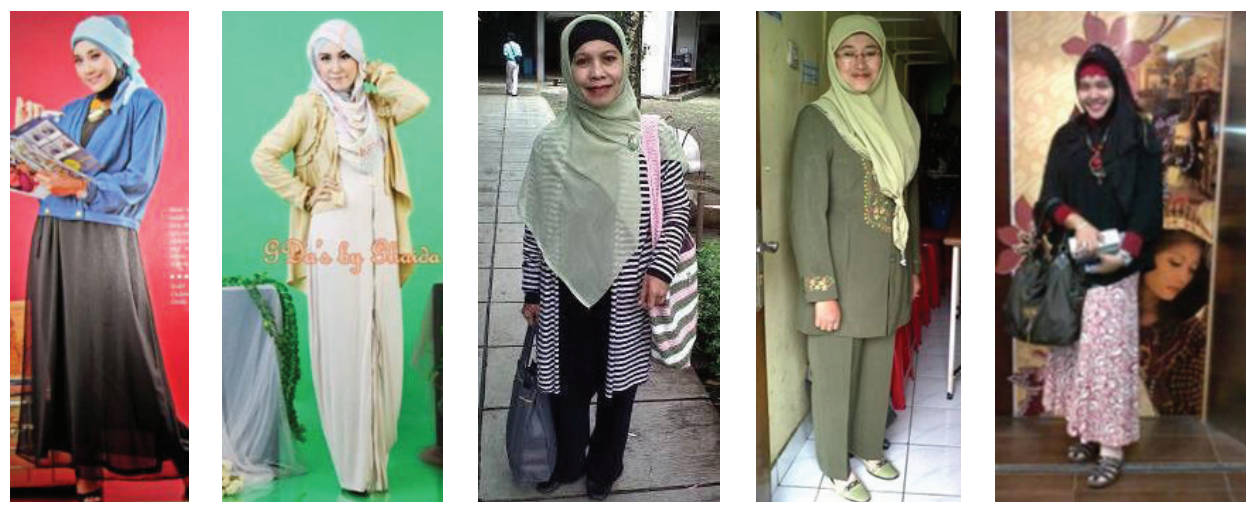

2. Gaya busana dengan siluet yang sesuai maupun mendekati konsep dasar busana kerja (poin 4-5) terdapat pada gambar:

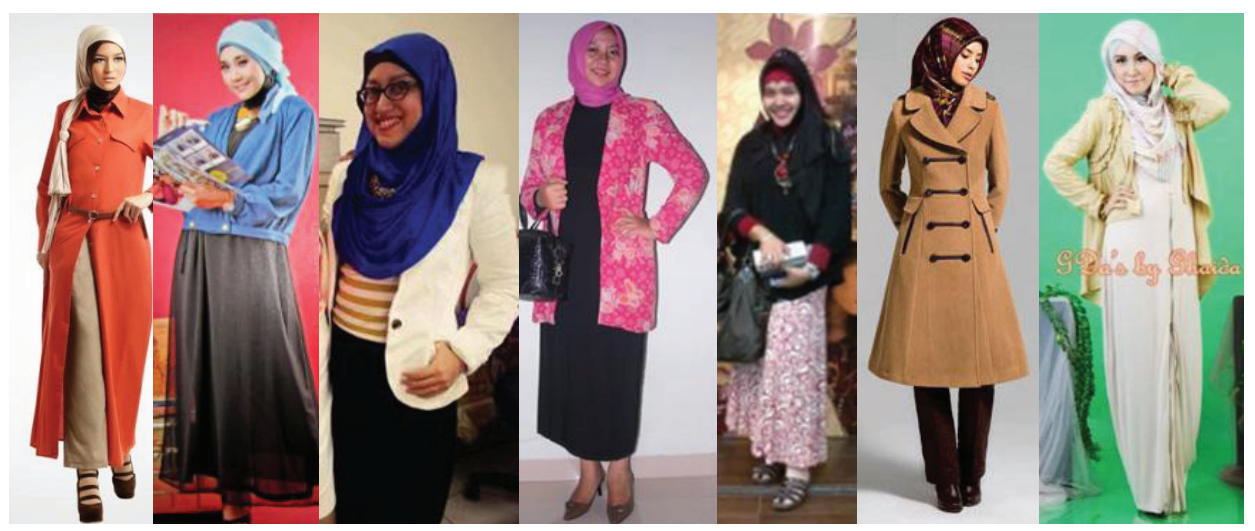

el Harakah Vol.15 No.2 Tahun 2013 
3. Irisan dari gaya busana dengan penerapan syariah dan konsep dasar busana kerja terdapat pada tiga gambar di bawah, dijelaskan dalam tabel berikut:

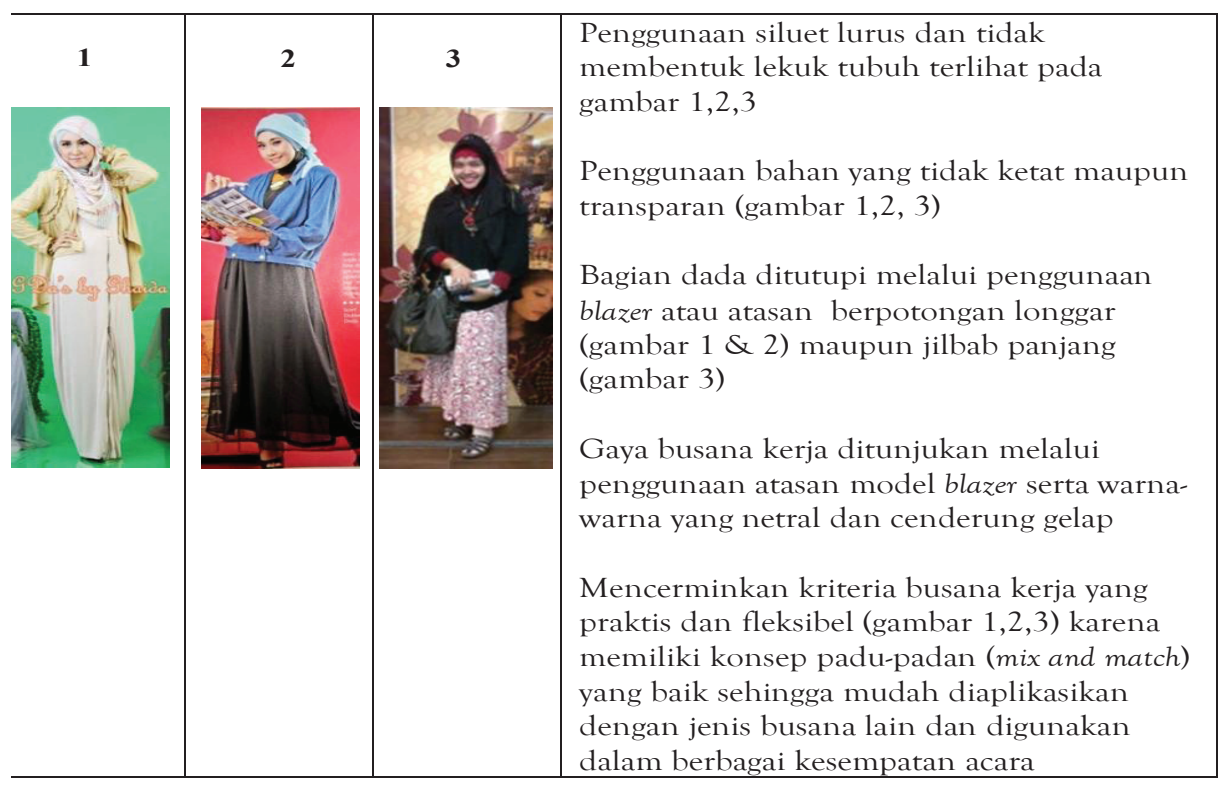

\section{Simpulan}

Kriteria busana kerja muslim yang sesuai dengan syariah dalam perspektif Islam tradisionalis khususnya modernis diantaranya tidak memiliki siluet yang membentuk tubuh atau tidak ketat (longgar) serta penggunaan material yang tidak transparan. Sedangkan kriteria busana kerja (formal maupun semi formal) lebih mengarah pada segi kepraktisan dalam bekerja, siluet yang sopan (tertutup), bahan yang tidak tipis atau transparan, nyaman digunakan dan tidak mengkilat, perawatan bahan yang mudah, serta penggunaan detail, ornamen, dan warna yang serasi-sederhana (tidak berlebihan). Beberapa contoh wujud visual dari kriteria tersebut dapat dilihat melalui analisis pada sejumlah gambar busana kerja muslimah, baik melalui majalah, situs jual-beli online, maupun dokumentasi pribadi. Berdasarkan hasil analisis gambar, salah satu jenis pakaian yang dapat digunakan sebagai busana kerja sekaligus memenuhi kriteria syariah adalah jenis blazer dengan warna-warna yang netral maupun gelap. Selain mudah dilakukan padupadan, blazer juga memiliki potongan longgar yang dapat menutup aurat. Busana kerja muslimah yang sesuai dengan kriteria syariah, konsep dasar busana kerja maupun tren, diharapkan dapat membantu karyawati muslimah untuk berhijab secara syar' $i$, profesional, dan trendi.

\section{Daftar Pustaka}


Dharsono, Poppy. 1993. Bagaimana Berbusana Serasi dan Muda. Majalah Femina: No.5

Endraswara, Suwardi. 2012. Buku Agama Jawa, Menyusuri Jejak Spiritualitas Jawa. Bantul, Yogyakarta: Lembu Jawa.

Prasetya, Heru. 2010. Buku Identitas Perempuan Indonesia: Status, Pergeseran Relasi Gender, dan Perjuangan Ekonomi Publik. Depok: Desantara.

Riyanto, Arifah \& Liunir Zulbahri. 2009. Modul Dasar Busana. Modul Mata Kuliah, Program studi Pendidikan Tata Busana Jurusan Pendidikan Kesejahteraan Keluarga. Fakultas Pendidikan Teknologi dan Kejuruan, Universitas Pendidikan Indonesia: Bandung.

Stone, Elaine. 2008. The Dynamics of Fashion. New York: Fairchild Books.

Sumbulah, Umi. 2010. Fundamentalisme Sebagai Fenomena Keagamaan. Blog Sivitas Akademik Fakultas Syariah UIN Malang. http://syariah.uin-malang.ac.id/index. $\mathrm{php} /$ komunitas/blog-fakultas/entry/fundamentalisme-sebagai-fenomenakeagamaan\#_ftn2 (diunduh pada Juni 2013).

Surtiretna, Nina dan Anne Rufaidah. 1995. Anggun Berjilbab. Indonesia: AlBayan.

Syafaq, Hammis. 2009. Menggali Akar Gerakan Fundamentalisme Islam Di Mesir. Al Afkar. Vol 19, No 1. http://ejournal.sunan-ampel.ac.id/ (diunduh pada Juni 2013).

Tualeka, Hamzah. 2009. Gerakan Neomodernisme Islam di Indonesia (Perspektif Nurcholish Madjid dan Abdurrahman Wahid). Al Afkar. Vol 19, No 1. http://ejournal.sunan-ampel.ac.id/ (diunduh pada Juni 2013).

Zenrif, Fauzan. 2011. Islam: Liberalisme, Radikalisme dan Fundamentalisme. Blog Sivitas Akademik Fakultas Syariah UIN Malang. http://syariah. uin-malang.ac.id/index.php/komunitas/blog-fakultas/entry/74 (diunduh pada Juni 2013).

Zulaikha, Ellya. 2003. Kajian Desain Terhadap Hibriditas dalam Gaya Jilbab di Indonesia. Tesis. Fakultas Seni Rupa dan Desain, Institut Teknologi Bandung. 